\title{
International academic mobility: an education opportunity for future nurses
}

\author{
Intercâmbio académico internacional: uma oportunidade para a formação do futuro \\ enfermeiro \\ Intercambio académico internacional: una oportunidad de formación para los futuros \\ enfermeiros
}

Jordana Lopes Carvalho*; Dirce Stein Backes**; Maria de Lurdes Lopes de Freitas Lomba***; Juliana Silveira Colomé ${ }^{* * * *}$

\begin{abstract}
Background: International academic mobility allows for the exchange of scientific and cultural knowledge, namely on health technologies, the sharing of information and experiences, and the increase of professional opportunities.

Objectives: To identify the benefits of international academic mobility for nursing education from the students' perspective. Methodology: We conducted an exploratory-descriptive study, with a qualitative approach, with a sample of 17 students who had participated in international mobility programs in the Franciscan University Center - Santa Maria/RS/Brazil and in the Nursing School of Coimbra/Portugal. Data were collected through semi-structured interviews and then submitted to content analysis.

Results: Data analysis resulted in 3 categories: Health in the home country vs. health in the host country - contextualizing professional knowledge and experiences; Academic mobility - possibility for the development of students' autonomy; and Opening horizons - cultural contributions in the process of academic mobility.

Conclusion: Academic mobility processes enable the contact with new clinical and research practices, which improves students' education and professional performance as future nurses.
\end{abstract}

Keywords: professional education; international educational exchange; nursing

\section{Resumo}

Enquadramento: O intercâmbio académico internacional possibilita novos conhecimentos científicos e culturais, incluindo tecnologias em saúde, partilha de saberes e experiências e ampliação das oportunidades profissionais.

Objetivos: Identificar os benefícios do intercâmbio para a formação do enfermeiro, na perspetiva dos estudantes.

Metodologia: Pesquisa exploratório-descritiva de cariz qualitativo. Participaram no estudo 17 estudantes que realizaram programas de mobilidade internacional no Centro Universitário Franciscano - Santa Maria/RS/Brasil e na Escola Superior de Enfermagem de Coimbra/Portugal. Os dados foram colhidos através de entrevistas semiestruturadas e submetidos à análise temática de conteúdo. Resultados: A análise dos dados resultou em 3 categorias: A saúde no país de origem vs. país de intercâmbio - contextualizando saberes e vivências profissionais, Intercâmbio académico - possibilidade de desenvolvimento da autonomia dos estudantes e, Ampliando horizontes - contribuições culturais no processo do intercâmbio académico.

Conclusão: Os processos de intercâmbio permitem a aproximação dos estudantes a novas realidades práticas e de investigação, o que contribui para a formação do estudante e um melhor desempenho profissional como enfermeiro, no futuro.

Palavras-chave: educação profissionalizante; intercâmbio educacional internacional; enfermagem

\footnotetext{
* Ph.D., RN, Franciscan University Center, 97010-430, Santa Maria, Rio Grande do Sul, Brazil [dana.lopes@ hotmail.com]. Contribution to the article: fieldwork and article writing, first author.

Address for correspondence: Santa Maria, 97010-491, Rio Grande Do Sul, Brazil.

** Ph.D., Associate Professor, Franciscan University Center, 97010-430, Santa Maria, Rio Grande do Sul, Brazi [backesdirce@ig.com.br]. Contribution to the article: assessment and supervision of this final graduation

project. $\mathrm{pt}$. Contribution to the article: literature search, elaboration and translation of the interview questions, supervision in the sample selection, and in the elaboration and review of the article for publication. ***** Ph.D., Associate Professor, Franciscan University Center, 97010-430, Santa Maria, Rio Grande do Sul, Brazil [julianacolome@yahoo.com.br]. Contribution to the article: Guidance in the choice of theme, literature search, supervision of all study steps, contributing to the research and article writing.
}

\section{Resumen}

Contexto: El intercambio académico internacional posibilita nuevos conocimientos científicos y culturales, incluidas las tecnologías en la salud, el intercambio de saberes y experiencias y la ampliación de las oportunidades profesionales.

Objetivos: Identificar los beneficios del intercambio para la formación del enfermero desde la perspectiva de los estudiantes. Metodología: Investigación exploratoria y descriptiva de naturaleza cualitativa. En el estudio participaron 17 estudiantes que realizaron programas de movilidad internacional en la Universidad Franciscana - Santa Maria/R/Brasil y la Escuela Superior de Enfermería de Coímbra/Portugal. Los datos se recogieron a través de entrevistas semiestructuradas y se sometieron a análisis del contenido temático.

Resultados: El análisis de los datos dio como resultado 3 categorías: La salud en el país de origen frente al país de intercambio - contextualizando conocimientos y experiencias profesionales; el intercambio académico como una posibilidad para el desarrollo de la autonomía de los estudiantes, y la ampliación de horizontes - contribuciones culturales en el proceso de intercambio académico.

Conclusión: Los procesos de intercambio permiten que los estudiantes se acerquen a nuevas realidades prácticas y de investigación, lo que contribuye a la formación del estudiante y a un mejor desempeño profesional como enfermero en el futuro.

Palabras clave: educación profesional; intercambio educacional internacional; enfermería

Received for publication: 16.03 .16

Accepted for publication: 18.07 .16 


\section{Introduction}

The socioeconomic, cultural and technological changes that have occurred worldwide in recent decades have created new training needs for citizens who increasingly need higher levels of education to be part of a knowledge-centered, border-free, and globalized world. As a result, the internationalization process that began in Europe back in 1945, due to the need for rebuilding the countries destroyed by World War II, became a priority in governmental agendas, with global guidelines for higher education. These guidelines indicate that internationalization must be included in the study plans and in the teaching and learning processes (Castro \& Cabral Neto, 2012). In 2014, the Erasmus program estimated that 650,000 European university students were away from their country of origin, participating in this mobility and cooperation process in the field of education (European Parliament and of the Council. Official Journal of the European Union no. 347, 2016).

Indeed, internationalization enhances the opportunity for a promising future in both academic and professional areas, and, as such, students feel motivated to increasingly participate in these processes. Through academic mobility, students wish to improve their linguistic skills and autonomy, and also have expectations concerning their professional training. Moreover, this type of experience promotes a major self-improvement, as it provides students with a broader view of the future.

Health-related mobility programs provide an understanding of the epidemiological and social reality in other countries, as well as new types of care, enabling health professionals, especially nurses, to contact with a different reality, capable of instigating change and innovation. Therefore, during the mobility process, health-related experiences, observations and activities can provide new experiences, as well as new knowledge on technologies and care processes (Oliveira \& Pagliuca, 2012).

In view of the above, this study is justified by the growing number of nursing students who have had the opportunity of participating in international academic mobility, being relevant and necessary to reflect on the students' possibilities for developing competencies and skills during their international mobility program. Thus, this study aims to identify the benefits of international academic mobility programs for nursing education from the perspective of students who participate in international mobility programs.

\section{Background}

The internationalization of higher education promotes the inclusion and development of the countries involved. Higher education institutions implement expansion procedures on their mobility programs in order to prepare their teachers and students to serve in a globalized world, with all its complex and continuously changing demands.

With this in mind, in Brazil, the Ministry of Education (MEC) agencies and the higher education institutions have encouraged the development of international mobility programs through academic agreements and scholarships in which the university student spends a few months or years at a partner institution, and the credits there obtained are recognized by the institution of origin (Dalmoni, Pereira, Silva, Gouveial, \& Sardinheiro, 2013). In this context, some opportunities should be highlighted, such as the Science without Borders (Ciência sem Fronteiras - CsF) program. The CsF aims to invest in the personal training of competencies and skills for knowledge advancement, as well as to increase the presence of researchers and students in international institutions of excellence. Moreover, it is committed to encouraging young talents and highly-qualified researchers in science to work in Brazil. This program comprises a total of 18 areas of undergraduate courses and offers a monthly grant to cover living expenses, didactic materials, airline tickets and health insurance, for a period of 12 months (Decreto n. ${ }^{0} 7.642$ de 13 de Dezembro, 2011). In Europe, the Erasmus mobility program gives students the opportunity to live in another country, learn a foreign language, and develop their adaptation skills. This program is one of the greatest achievements of the European Union. In 2011, 250,000 students had the opportunity to study or do an internship in another country within the scope of this program, in which teachers can also participate. This program contributes to the quality of higher education in Europe, and promotes the potential of Europe's human and social capital, based on the principles of lifelong learning (Regulation (EU) No. 1288/2013 of 11 December, 2013). 
One of the students' main motivations to participate in international mobility programs is their desire for improving their knowledge with new experiences, as well as creating opportunities for future work. International education experiences provide students with relevant knowledge for their future academic and professional lives, and their experiences at a foreign institution are a possible reality that allows them to differentiate themselves professionally, particularly through internationalization (Fassarella, Silva, \& Figueiredo, 2013).

\section{Research questions}

Taking into account that the expansion process of mobility programs, especially in the Nursing field, needs to be valued and assessed, we formulated the following question: what are the benefits of international academic mobility programs for future nurses' training, from the perspective of nursing students?

\section{Methodology}

We conducted an exploratory-descriptive study with a qualitative approach. The study was conducted between January and October of 2015 with students attending the Nursing Bachelor's Degree at the Franciscan University Center, in Santa Maria, state of Rio Grande do Sul, Brazil, and students attending the Nursing Bachelor's Degree at the Nursing School of Coimbra (ESEnfC), in Coimbra, Portugal. The study involved third- and fourth-year students, applying the following inclusion criteria: currently participating or having participated in the past 6 months in an international academic mobility program, accepting to voluntarily participate in the study, and signing an informed consent form.

The ESEnfC population was composed of 52 outgoing students (students of the ESEnfC) who went on mobility for 12 weeks to Belgium, Bulgaria, Spain, Finland, Hungary, England, Italy, Turkey, Romania, Brazil and Macao, and 35 incoming students from Spain, Estonia, Brazil and Finland. An intentional sample of 10 participants was selected so as to, on the one hand, include both outgoing and incoming students in the sample and, on the other hand, diversify, as much as possible, the mobility experiences in different countries. Thus, in this sample, the outgoing students went on mobility to Belgium, Spain, Hungary, Italy and Macau (China), and the incoming students came from Spain, Estonia and Brazil.

The Franciscan University Center population was composed of four German incoming students for a period of 6 months and three outgoing students who carried out a 12-month program in Portugal, but whose institution of origin was the Franciscan University Center. Thus, in Brazil, the study sample consisted of seven students, which represented the total number of students who met the inclusion criteria during the development of this study. Taking into account both scenarios, 17 students participated in this study. Data were collected through a semistructured interview (Fraser \& Gondim, 2004), which was recorded and then transcribed in full. The interviews were performed in English, Spanish and European Portuguese and later translated and transcribed into Brazilian Portuguese.

Data were analyzed according to the Thematic Content Analysis, and performed in three steps: 1) pre-analysis - considered the stage of organization, where the initial research questions objectives were reanalyzed with the purpose of operationalizing and systematizing the ideas. 2) exploration of material used to analyze the categories arising from the preanalysis. 3) processing and interpretation of results (Minayo, 2010).

Data saturation was not achieved with regard to the content of the interviews due to the limited number of students who met the inclusion criteria and were available to participate in the study in both countries. However, we believed that a sample composed of 17 students was enough to meet the research objectives. We met all ethical principles as in accordance with Resolution no. 466 of 12 December of the National Council of Health, National Commission of Ethics in Research (2012). The study was conducted after being approved by the Research Ethics Committee of the Franciscan University Center, according to opinion no. 988.812. In order to ensure the participants' anonymity, we used codes to identify them in the study, using the letter P for participant, followed by numbers from 1 to 17, and the three initial letters of the student's country of origin. 


\section{Results}

Data analysis resulted in the following three thematic categories: Health in the home country vs. health in the host country: contextualizing professional knowledge and experiences; Academic mobility: possibility for the development of students' autonomy; and Opening horizons: cultural contributions in the process of academic mobility.

\section{Health in the home country vs. health in the host country: contextualizing professional knowledge and experiences}

Initially, the mobility experience led students to compare the health systems in their home country to the country where they had developed their mobility program. This observation allowed for the recognition of the merits and weaknesses of each reality under analysis, allowing students to have a critical attitude. The health issue, based on universality, was highlighted when compared to health care systems which do not provide full coverage concerning the different types of health care:

In Spain we have a universal health system which we all pay for; then if you pay, you are cared for; here in Portugal, it's the same, but in emergency services you have to pay an additional fee. (P7SPA; 30-01-2015)

In Germany, we have to pay health insurance, each person needs to have a health plan, so the best place to be treated has already been chosen. We don't have a primary health care system, as they have in Brazil. (P14-GER, 14/05-2015)

When comparing the nurse's role in the different countries, the students highlighted issues related to the nurses' autonomy in technical and administrative issues. "The nursing education system works better in Brazil than in Germany. In Germany, the doctors tell us how to do things, but in Brazil nurses already know what they're supposed to do." (P17-GER; 14-05-2015)

In Barcelona, the nurse is more autonomous than in Portugal; the nurse prescribes laboratory tests and some routine exams, whereas in Barcelona they don't; nurses and doctors interact more and work as a team. (P4-SPA; 21-02-2015)

On the other hand, technology issues related to equipment, infrastructures and healthcare in other countries were compared to the reality of the country of origin.
"I observed that they have much better technological conditions in Portugal than in Brazil. Unfortunately, the health care quality is much higher Portugal than in Brazil." (P11-BRA; 08-08-2015)

There are positive things in Italy that I would bring to Portugal and there are things in Portugal that I would take [to Italy]. From Portugal I would take wound management and from Italy I would bring the software that they have on medication, which is much better, everything is computerized. (P1-PORT; 02-17-2015)

\section{International academic mobility: a possibility for the development of student's autonomy}

From the students' perspective, the mobility experience offered new possibilities for the development of autonomy, which may contribute to their academic, personal and professional development.

It changed my life a lot, I went on mobility and I'm sure that I came back with more mature thoughts. This was a very important experience to me and also helped me to become independent. (P11BRA; 13-08-2015)

This was the perfect opportunity to live my own life, away from my parents. I came from Estonia to Portugal alone, without any friend, not knowing anyone, and here people don't speak English. It was a bit complicated for me, but these opportunities gave me the chance to learn a new language. (P9-EST; 25-02-2015)

As important as gaining independence is the students' ability to reorganize their own life. In a different country, with different people and cultures from that they were used to, these students contacted with other realities and ways of life. In their own words:

"Here I was able to live alone, having to do things by myself, I became more confident and self-assured" (P16-GER; 14-05-2015).

"It was all about becoming more self-assured, because I was in another country and had to speak in a different language" (P8-SPA; 21-02-2015).

Students also highlighted issues related to making more conscious decisions and learning to be more responsible and creative, because the work environment often does not offer all the necessary materials.

"The program has helped me to grow both personally and regarding what it means to be a nurse, and also 
to make wiser choices and study harder" (P12-BRA, 08-08-2015).

"The hospital lacked a lot of material, so I learned that we have to do things in the best possible way using another material; I grew up a lot, became more imaginative and tried not to depend on any specific material" (P10-SPA; 30-01-2015).

\section{Opening horizons: cultural contributions in the process of academic mobility}

The new knowledge and cultural experiences brought about by the mobility program were also highlighted in the study. According to the students, searching for new academic paths made them outline their objectives based on the different realities experienced on a daily basis.

"It is a unique and fantastic experience that enables personal growth. Every person should experience this, get to know new places, new people, new languages." (P8-SPA; 21-02-2015)

"I met a lot of different people and cultures in another country, I have learned to operate in different ways, which helped me grow." (P10-SPA; 21-02-2015)

For students, the possibility of participating in mobility programs has strengthened their pre-professional trajectory, therefore representing a differential in their professional practice, opening new horizons:

"In addition to personal benefits, it also brought about benefits for my career. We can contact with other realities and learn new things, as well as observe the main differences" (P4-PORT; 24-02-2015).

In addition to the knowledge I gained in the Health and Nursing areas, I got to know other cities, I was able to travel, discover new places which are really worth visiting, and made new friends from other countries. This contributes to the profession. (P1-PORT; 13-02-2015)

Despite its many perspectives and expectations, the mobility program also brings about challenges and obstacles that must be addressed throughout this experience. Our data highlighted the linguistic difficulties, which were almost unanimous among the participants, and often caused by the host country's unpreparedness to receive students from other countries:

"I think that it was the language, I'm now able to understand people, but it was very difficult at the beginning, people in Portugal speak very fast and we also met many Spanish people so we did not invest a lot in learning the language." (P8-SPA; 21-02-2015). "I think that the biggest difficulty was language, when I got here I realized that people didn't speak English. I would say something and they wouldn't understand it." (P9-EST; 25-02-2015).

"The most important difficulty is the language, it is really hard to communicate." (P17-GER; 14/05-2015). Some students highlighted other problems besides the language, such as problems related to nursing education in another country and to how degrees and the information are organized in different institutions. The terminology, the types of care and the routines in clinical practice were highlighted as challenges to be overcome:

The main difficulties are the bureaucratic terms, in the first few days we really wanted to go home, because they don't seem to realize that we're not like the other students and they wanted us to be, they use terminology here that we don't use in Spain and they wanted us to use it. (P6-SPA; 2102-2015)

"There's no patient hygiene there, and it is an important thing because it allows us to better assess patients since operational assistants have no specific training to do do that." (P7-SPA; 30-01-2015)

\section{Discussion}

Higher education institutions seek to open new doors through internationalization, so as to expand their technical and scientific knowledge and be able to train more qualified and entrepreneurial professionals. Therefore, the globalized world assists by removing borders, integrating different realities and promoting the exchange between various types of knowledge and cultures (Schaurich, Cabral, \& Almeida, 2007).

International academic mobility aims to promote the development of students' knowledge and skills, as well as of academic cooperation and institutional relationships (International Academic Mobility, 2002). Thus, the demand for this experience has increased, and students need to be aware of internationalization policies to ensure that the mobility process is clear and easily accessible (Fahey \& Kenway, 2010).

The results of this study have shown that the international experience has increased students' possibilities of new personal and professional experiences. Indeed, and as according to Oliveira 
and Pagliuca (2012), participants have highlighted that they have to be prepared for this experience, because it requires the capacity to cope with unforeseen circumstances and changes in behaviors and values. During the mobility program, students felt accountable for their own actions and attitudes in another country, which seemed to stimulate the maturation of attitudes and approaches, with an impact on independence and autonomy.

We observed that their experience as nursing students in another country prompted the analysis of different realities, allowing for new approaches and contextualizing the knowledge acquired, and added new perspectives to rethink both Nursing care and the health system of the home and host countries.

The opportunity to become familiar with the context of health outside the students' home country led them to develop a proactive and innovative attitude which helped them change specific aspects in the work environment, making a difference in care provision. In relation to nursing, we highlight the importance of knowing new technologies and ways to provide nursing care.

According to Oliveira and Pagliuca (2012), the process of developing an internship in clinical settings different from the reality experienced on a daily basis increases the students' observation skills and gives them the possibility to compare different realities. This experience can make them better prepared to deal with daily adversities, because they expand their vision, from a local to an international perspective, based on a multidimensional construction process that culminates in more autonomy in life. The study showed that the health-related differences between the realities encourage students to wanting to know and understand them in the best possible way, which offers new possibilities for the expansion of ideas and opportunities for change, contributing to make them more entrepreneurial professionals in the future.

In fact, the environment where the professional nurse is integrated needs to be dynamic and interactive, which includes knowledge, skills and attitudes related to professional leadership and autonomy, thus transforming the nurse into a more proactive and innovative professional (Balsanelli \& Cunha, 2015).

According to the students who participated in a mobility program, it is clear that this process has contributed to their personal and professional growth, as dealing with unfamiliar situations required maturity.

The sampled students also highlighted the development of autonomy as a result of the mobility program; however, it requires maturity in the choices and attitudes. This has a personal and academic impact, because students need to improve their ability to deal with difficulties, thus being able to achieve greater independence in different life domains. The advantages and benefits of this process go beyond academic learning; they involve personal and psychological development and independence, which promote overall growth. However, the family's presence and support are essential, even if from a distance (Oliveira \& Pagliuca, 2012). Interestingly, none of the participants in this study mentioned this need for family support.

The study results indicate that the students' participation in the mobility process offers opportunities and produces social and cultural effects, because the knowledge built from this experience allows them to transform reality, because they contact with different realities from those with which they are familiar. Students participating in these programs have the opportunity to experience several situations of cooperation between the academia and the reality, as well as for observing research projects that will lead to the further development and demand for different types of knowledge (Krahl et al., 2009).

Students also highlighted the learning process and its relationship with the cultural differences and the challenges and obstacles that they face during this journey, which need to be more maturely and objectively addressed. The experience of living in another country opens new opportunities for the future, and helps overcoming difficulties, because students have to adapt to and cope with the challenges arising during this process, becoming emotionally stronger at the end (Santos, Leite, \& Valente, 2014; Souza, 2008). To sum up, and as according to Babadué, Carnevale, Paula, Padoin, and Neves (2013), interculturality is practiced during the experience abroad through the relationships established with other professionals and other cultures.

According to the students, language was one of their biggest challenges, as it often hampered the development of both social and professional relationships. During training, it is also important to face some obstacles, because they require new 
interpretations from students, thus promoting a more comprehensive perspective of health (Silva, Garanhani, \& Peres, 2015).

Although the methodological process is clearly explained, this study had some limitations. The fact that this was a cross-sectional study developed in two different countries, in a short period of time, limited the number of students simultaneously available and eligible. However, the qualitative approach focuses primarily on the meanings assigned by participants to the situations experienced, and, for this reason, it does allow for an understanding of all those who intervene in this process. On the other hand, the fact that the interviews were mostly conducted in a language different from the researchers' or the participants' native language may have conditioned the interpretation of questions and answers. Even so, we believe that this study contributes to a better understanding of the challenges faced by these students and the specific contributions of international academic mobility to nursing education, namely since students reported becoming more sensitive to the differences between countries and the different caring possibilities from a cross-cultural perspective.

\section{Conclusion}

The process of globalization development has been expanding in recent decades and higher education institutions have been trying to keep up with this process in order to expand horizons and new borders. To this end, they have promoted international academic mobility programs. These processes are becoming increasingly frequent, as shown by the increased number of agreements between higher education institutions and opportunities for students to learn about different realities and have new experiences, thus fostering their personal and professional development.

This study addressed the international academic mobility as a training opportunity for nursing students, and allowed identifying students' views on health and the nurse's performance in their country of origin and abroad by comparing realities and showing the personal and professional development resulting from this experience, as well as the difficulties experienced throughout this process.
The possibility of carrying out an international mobility program also reinforced the students' preprofessional trajectory, making them better prepared to face future adversities in everyday life, and providing them with greater autonomy and safety. The contact with an unfamiliar world enables them to strengthen and expand concepts in the health and care domains, transforming nursing thinking and practice based on a multidimensional health-related perspective.

Therefore, students' participation in these processes has multiple advantages. In addition to providing the knowledge of new languages, cultures and traditions, it creates the opportunity to expand professional networks beyond the country of origin, given that professionals need to be increasingly qualified to be integrated into different work environments and different forms of nursing care, in an increasingly globalized world.

Thus, academic mobility processes stand out for being allies in helping students contact with new realities and research practices, which tends to qualify the future nursing professional from a cross-cultural perspective.

Given the current reality of intense mobility of people from different regions of the world, we suggest the development of further studies to understand and assess how the nursing students' experience of international mobility influences their future clinical practice, as professionals, and the care that they provide to individuals from different backgrounds and cultures, with different rituals and ways of life.

\section{References}

Babadué, R. M., Carnevale, F., Paula, C. C., Padoin, S. M., \& Neves, E. T. (2013). Participação em programa de intercâmbio internacional: Contribuições da experiência de graduaçãosanduíche em enfermagem. Revista de Enfermagem da UFSM, 3(3), 555-562. doi: 10.5902/2179769291577922

Balsanelli, A. P., \& Cunha, I.C. (2015). Liderança do enfermeiro em unidade de terapia intensiva e sua relação com ambiente de trabalho. Revista Latino-Americana de Enfermagem, 23(1), 106-113. doi: 10.1590/0104-1169.0150.2531

Castro, A. A., \& Cabral Neto, A. (2012). O ensino superior: A mobilidade estudantil como estratégia de internacionalização na América Latina. Revista Lusófona de Educação, 21(21), 69-96. Retrieved from http://revistas.ulusofona.pt/index. php/rleducacao/article/view/3082

Conselho Nacional de Saúde, Comissão Nacional de Ética em Pesquisa. (2012). Normas para pesquisas envolvendo 
seres humanos: Manual resolução CNS $n^{\circ} 466 / 12$ e outras. Brasília, Brasil: Autor.

Dalmoni, I. S., Pereira, E. R., Silva, R. M., Gouveial, M. J., \& Sardinheiro, J. J. (2013). Intercâmbio acadêmico cultural internacional: Uma experiência de crescimento pessoal e científico. Revista Brasileira de Enfermagem, 3(66), 442447. doi: 10.1590/S0034-71672013000300021

Decreto $n^{0}$ 7.642/2011 de 13 de Dezembro de 2011. Presidência da República. Brasília, Brasil. Retrieved from https://www. planalto.gov.br/ccivil_03/_ato2011-2014/2011/decreto/ d7642.htm

European Commission. (2016). Education and training: Supporting education and training in Europe and beyond. Retrieved from http://ec.europa.eu/education/tools/ statistics_en.htm Fahey, J., \& Kenway, J. (2010). International academic mobility: Problematic and possible paradigms. Discourse: Studies in the Cultural Politics of Education, 31(5), 563-575. doi: 10.1080/01596306.2010.516937

Fassarella, C. S., Silva, L. D., \& Figueiredo, M. C. (2013). Doutorado em enfermagem em regime de cotutela internacional: Uma possibilidade a ser experimentada. Revista enfermagem da UERJ, 21(5), 682-686. Retrieved from http://www.epublicacoes.uerj.br/index.php/enfermagemuerj/article/ view/10055/7838

Fraser, M. T., \& Gondim, S. M. (2004). Da fala do outro ao texto negociado: Discussões sobre a entrevista na pesquisa qualitativa. Paidéia, 14(28), 139-152. doi: 10.1590/\$0103863X2004000200004

International Academic Mobility. (2002). Formative evaluation of the International Academic Mobility initiative: Final report. Retrieved from http://files.eric.ed.gov/fulltext/ED519582.pdf

Krahl, M., Slobeslak, F., Poletto, D. S., Casarin, R. G., Knof, L. A., Carvalho, J., \& Motta, L. A. (2009). Experiência dos acadêmicos de enfermagem em um grupo de pesquisa. Revista Brasileira de Enfermagem, 62(1), 146-150. doi: 10.1590/S0034-71672009000100023

Minayo, M. C. (Org.). (2010). Pesquisa social: Teoria, método e criatividade (14ª ed.). Petrópolis, Brasil: Vozes.

Oliveira, M. G., \& Pagliuca, L. M. (2012). Programa de mobilidade acadêmica internacional em enfermagem: Relato de experiência. Revista Gaúcha de Enfermagem, 33(1), 195198. doi: 10.1590/S1983-14472012000100026

Regulation (eu) no 1288/2013 of 11 December. Official Journal of the European Union L $347 / 50$ of 2013. The European Parliament and the Council of the European Union. Brussels, Belgium

Santos, W. A., Leite, B. S., \& Valente, G. S. (2014). O intercâmbio acadêmico internacional como estratégia educativa cultural: Relato de experiência. Revista Enfermagem Profissional, 1(2), 304-314. Retrieved from http://www.seer.unirio.br/ index.php/enfermagemprofissional/article/view/3693/ pdf_1407

Schaurich, D., Cabral, F. B., \& Almeida, M. A. (2007). Metodologia da problematização no ensino em Enfermagem: Uma reflexão do vivido no PROFAE / RS. Escola Anna Nery Revista de Enfermagem, 11(2), 318-324. doi: 10.1590/S141481452007000200021

Silva, J. P., Garanhani, M. L., \& Peres, A. M. (2015). Sistematização da assistência de enfermagem na graduação: Um olhar sob o pensamento complexo. Revista Latino-Americana de Enfermagem,23(1), 59-66. doi: 10.1590/0104-1169.0096.2525

Souza, K. V. (2008). Intercâmbio educacional internacional na modalidade doutorado sanduíche em enfermagem: Relato de experiência. Escola Anna Nery Revista de Enfermagem, 12(2), 358-363. doi: 10.1590/\$1414-81452008000200025 

